\title{
REKONSTRUKSI NILAI MORAL KEWARGANEGARAAN BERDASAR ANALISIS SEMANTIK TERHADAP UNGKAPAN KULTURAL MASYARAKATSUNDA
}

\author{
Solihin Ichas Hamid ${ }^{1}$ \\ Tuti Istianti ${ }^{2}$
}

\begin{abstract}
ABSTRAK
Studi ini, merupakan kajian pendahuluan dan penelusuran konseptual berkenaan dengan ungkapan idiomatik dalam tradisi kultural masyarakat Sunda yang berfungsi menjadi 'petatah-petitih' dalam bentuk Babasan dan Paribasa dalam perspektif Nilai Moral Kewarganegaraan. Untuk mendapatkan gambaran berkenaan dengan standar acuan, dilakukan analisis semantik atas muatan makna ungkapan idiomatik berdasarkan tema kewarganegaraan, yang merupakan sejumlah nilai kebaikan hingga kebajikan, baik bersifat personal, sosial dan institusional; yang direkonstruksi ke dalam 7 kategorisasi sikap moral yakni : 1) ramah, santun, tahu diri, rendah hati); 2) sabar, ikhlas, besar hati, terbuka, lurus / jujur ; 3) bersahabat, suka menolong) ; 4), pengabdian, kesiagaan dan kewaspadaan ; 5) teguh membela kehormatan, kesatria, berani dan perwira; 6) ulet, tangguh, ajeg, berorientasi mutu (pekerjakeras dan cerdas) mandiri ; 7) adil terhadap sesama, arif bijaksana. Keberadaan seutuhnya pemakaian Babasan dan Paribasa ada dalam setting waktu dan tempat tertentu yang menunjukan kuatnya institusi kolektif dalam memelihara dan melestarikan warisan bahasa sebagai bagian dari sistem budaya etnik lokalnya. Untuk itu, selain identifikasi dan sekaligus klasifikasi hingga kategorisasi isi terhadap objek kajian ini yang telah menjadi himpunan yang bersusun secara alfabetik dan menjadi fakta literer, kelengkapan dan keutuhannya tetap ada pada lingkup komunitas praksis penggunaan bahasa Sunda itu sendiri. Sehingga selain terhadap sumber tertulis, penelusuran tetap dilakukan secara etnografis melalui wawancara mendalam, kegiatan berperanserta dan analisis dokumentasi lainnya pada lingkup kehidupan keseharian manusia Sunda, baik secara personal, kelompok, dan komunitas besar pendukung sistem adat tradisional, baik pada lingkup homogen di pedalaman maupun realitas dinamis sebagai bagian dari heterogenitas warga desa / kota di luar situs. Masyarakat pemelihara Adat di Kabupaten Cigugur Kuningan memiliki representasi menjadi lokasi pilihan, karena mewakili ragam dinamika sebagaimana perkembangan masyarakat Sunda umumnya, pada moment dan event tertentu menghadirkan kolaborasi dan konfigurasi apresiasi seni budaya tradisional secara bersama dan bersatu dengan pemelihara nilai-nilai luhur adat lokal lainnya di Nusantara.
\end{abstract}

Kata Kunci : Rekonstruksi, Ungkapan Kultural, Idiomatik, Babasan-Paribasa, Semantik, Nilai-Moral Kewarganegaraan, 7 Kategori Tema Kewarganegaraan, Masyarakat Sunda :

\footnotetext{
${ }^{1}$ Dosen PGPAUD UPI Kampus Cibiru

${ }^{2}$ Dosen PGPAUD UPI Kampus Cibiru
} 


\section{A. PENDAHULUAN}

Hidup bernegara dalam kehidupan kultural manusia dan masyarakat Sunda khususnya dan Nusantara umumnya tidaklah dimulai sejak jaman Republik ini didirikan, yakni pasca Proklamasi 17 Agustus 1945. Melainkan jauh ke masa lalu, masa kadatuan Nusantara berjaya, dan melakukan hubungan dengan bangsabangsa dan negara lain di Asia khususnya hingga bangsa Eropa. Karena itu, standar acuan perilaku hidup berbangsa dan bernegara baik ke dalam maupun ke luar, sejatinya telah ada menjadi bagian dari produk kebudayaan dan keadaban sesuai jamannya. Bukti adanya nilai-moral kewarganegaraan yang hidup dan dianut oleh komunitas etnik sebagai satuan bangsa di Nusantara umumnya, dapat dilacak pembuktiannya pada sejumlah artefak kehidupan kultural yang tersisa. Yang menggambarkan adanya simbol-simbol pengaturan dan keteraturan kehidupan bersama pada satuan wilayah, baik besar ataupun kecil yang disebut Negara - meski masih bersifat monarchi.

Babasan dan Paribasa, sebagai salah satu bentuk idiomatik berupa ungkapan lisan yang terlahir dari adanya interaksi sosial budaya komunitas manusia pendukung system kebudayaan tersebut, secara konseptual menyimpan refleksi gambaran kehidupan berkenaan dengan sifat, keadaan hingga tindakan yang menunjukan nilai baik atau buruk, baik bagi kepentingan personal sebagai pribadi di dalam satuan kecilnya sebagai anggota keluarga, maupun dalam lingkup kebersamaan sebagai warga masyarakat, dan bentuk puncaknya yakni organisasi hukum yang disebut negara.

Karena itu, kesadaran hidup bermasyarakat, berbangsa dan bernegara (social national and citizenship awarness) yang keberadaannya menandai dan menjadi acuan kehidupan masyarakat modern, baik di negara-negara maju maupun Republik yang baru terbentuk pasca kolonialisasi. Bukanlah sebuah loncatan baru, melainkan aktualisasi baru dari jaman baru. Artinya, bahwa aktualisasi tersebut telah ada sejak jaman kadatuan dunia, termasuk di bumi Nusantara. Untuk itu, pencarian terhadap artefak yang menyisakan ekpresi budaya dalam kehidupan berbangsa dan bernegara, menjadi penting setidaknya dalam kerangka membangun kembali semangat kebangsaan, semangat kebersamaan atas identitas dan kepemilikan nilai-nilai potensial kultural yang ada, agar menjadi kekuatan aktual dalam mendukung pencapaian cita-cita mulia negara bangsa sebagaimana termaktub dalam Pembukaan UUD 1945

Permasalahan pokok penelitian ini dapat dirumuskan, dalam 2 pertanyaan penelitian sebagai berikut :

1. Adakah Nilai-Moral Kewarganegaraan dalam Babasan dan Paribasa sebagai salah satu bentuk idiomatik yang hidup dalam tradisi kultural masyarakat Sunda?

2. Bagaimanakah Muatan Nilai-Moral Kewarganegaraan yang terdapat dalam tradisi kultural manusia Sunda diaktualisasikan dalam kehidupan bermasyarakat, berbangsa dan bernegara?

Sesuai dengan rumusan permasalahan di atas, tujuan penelitian ini antara lain: 
1. Mengidentifikasi keberadaan Nilai-Moral Kewarganegaraandalam ungkapan Babasandan Paribasa, sebagai salah satu bentuk artefak kehidupan kultural masyarakat Sunda berdasar analisis semantik

2. Mendeskripsikan muatan konseptual Nila-Moral Kewarganegaraan yang terdapat dalam tradisi kultural masyarakat Sunda, dan aktualisasinya dalam praksis kehidupan bermasyarakat, berbangsa dan bernegara

Penelitian ini memiliki relevansi dengan sejumlah studi terdahulu berkenaan ikhtiar pendidikan nilai-moral dalam berbagai perspektif bidang keilmuan sejumlah mata pelajaran, yang secara sinergis masing-masing dapat berperan menjadi sarana dan media selain memfungsikan dirinya sebagai isi (kontens based) dari sebuah tujuan parsial pembelajaran.

Penelitian ini sendiri, berpijak pada kepentingan konteks keilmuannya, yakni Pendidikan Kewarganegaraan direkontruksi menemukan hubungan dan penguatan bagi pencapaian hajatnya, yakni membentuk performan warga negara yang baik (Good Citizenship) yang secara klasik telah menjadi subtansi tujuan pendidikan nasional setiap negara-bangsa, tidak kecuali bagi bangsa Indonesia. Artinya, bahwa menyiapkan warganegara yang baik, memiliki karakter yang diharapkan oleh kepentingan perjuangan negara dan bangsanya, telah menjadi mozaik pendidikan global, kendati disisi lain harus berhadapan dengan global paradok yang tidak dapat dianggap sebagai bukan ancaman. Dalam kerangka itu, pencerian, dan penguatan kembali keinsyafan atas nilai-nilai yang bersumber dari kearifan lokal, yang terdapat dalam sejumlah artefak kehidupan kultural tradisional itu sendiri, salah satunya dalam dan dari Idiomatik berupa petatahpetitih yang dalam konteks bahasa Sunda disebut papagah-peupeujeuh yang terdapat dalam Babasan dan Paribasa menjadi sebuah studi pendahuluan yang menarik untuk dilakukan.

\section{B. KAJIAN PUSTAKA}

Sebagai kajian teoritik penelitian ini, dapat diketengahkan telaah pustaka berkenaan dengan : 1) Hakikat Nilai-Moral Kewarganegaraan, dan 2)Kajian NilaiMoral dalam Ungkapan Kultural Masyarakat Sunda; 3) Analisis Semantik dalam memahami dan mengkonstruksi muatan Nilai-Moral kedalam Tema Kewarganegaraan

\section{Hakikat Nilai-Moral Kewarganegaraan \\ a. Hakikat Nilai dan Moral}

Nilai adalah salah satu objek kajian filsafat berkenaan dengan sesuatu yang terkandung di dalamnya, sehingga nilai dapat mencerminkan harga, kegunaan atau kekuatan bergantung dari sudut dan perspektif apa melihatnya. Karena itu, sesuai dengan aliran filsafat yang menjadi dasar perspektifnya, ragam pengertian nilai dapat dideskripsikan, setidaknya dari fungsi material atau imaterial dan diantaranya, yakni fungsi vital.Dalam konteks hubungan dengan manusia sebagai subjek peradaban, dijelaskan oleh Notonagoro (Ichas Hamid: 2005) : 1) nilai material melihat kegunaan atau fungsi dasar ujudiahsuatu benda bagi kebutuhan fisik-jasmaniah manusia; 2)nilai Vital, memaknai kegunaan atau fungsi sesuatu bagi kepentingan aktivitas manusia; dan 3) nilai imaterial, menunjuk kekuatan 
yang ada pada diri manusia sehingga bersifat abstrak dan kompleks, karena itu meliput potensi diri manusia secara ruhaniah / spiritual, berupa kemampuan logika, etika dan estetika hingga religi. Dalam perspektif lain, karena sesuatu dipandang bernilai atau tidak bergantung juga pada sudut pandang dan kepentingan diri manusia secara relatif, para akhli menyatakan bahwa suatu nilai dapat dikategorikan subjektif dan objektif. Nilai subjektif bergantung pada sudut pandang siapa dapat berbeda satu sama lain. Sedangkan nilai objektif melekat pada koeksistensi sesuatu, bisa benda atau non-benda yang memiliki fungsi dan kegunaan dalam keberadaannya bagi kepentingan aktivitas manusia.

Terhadap ujud nilai objektif ini, sesuai dengan karakteristik dan aktualitasnya dalam kehidupan masyarakat, dibedakan pula antara Nilai Dasar, Nilai Instrumental dan Nilai Praksis. Pertama, yang di maksud sebagai Nilai Dasar, disebut juga nilai ontologi, merupakan hakikat atau intisari terdalam dari nilai tersebut, fungsinya menjadi sumber norma yang dijabarkan ke dalam suatu kehidupan yang bersifat praktis; kedua, Nilai Instrumental, adalah penjabaran nilai dasar dengan formulasi dan parameter atau ukuran yang jelas, menjadi suatu eksplisitasi dari nilai dasar, bila dikaitkan dengan prilaku menjadi suatu norma moral, dan bila dikaitkan dengan organisasi negara menjadi kebijaknasnaan; ketiga, Nilai Praksis, merupakan penjabaran dari nilai instrumental dalam suatu kehidupan yang nyata. Dari uraian di atas, jelas bahwa nilai-moral menjadi salah satu sisi atau bagian dari makna nilai secara keseluruhan, dan moral khususnya sebagai norma menjadi eksplisitasi nilai dasar yang di bangun di dalam kerangka pandangan luhur (filosofik) atau keyakinan suci (iman Keagamaan) umat manusia.

\section{b. Nilai-Moral Kewarganearaan}

Nilai-nilai kewarganegaraan secara fenomenologistelah ada dalam kehidupan masyarakat seiring terbentuknya Negara sebagai organisasi pemerintahan di dalam masyarakat dari masa ke masa. Itu artinya, dalam ujud kehidupan kultural tradisional sekalipun, kesadaran hidup bernegara dalam makna menjalankan kelangsungan hidup dan kehidupan ada dalam aturan, dan sebagai anggota dari komunitas berkewajiban menjunjung tinggi lebih dari sekedar menghormati, dan melaksanakan segala aturan yang mengikat dirinya. Suatu keadaan yang tidak sebaik adanya dibanding dengan heterogenitas kehidupan masyarakat modern. Sungguhpun ke dalam kehidupan masyarakat modern dalam kejamakannya dapat diintrodusikan segala ikhtiar yang lebih maju dalam bentuk pendidikan secara komprehensif, informal, formal dan non-formal selain sumbangan yang bisa dipetik dari lingkup sosial kultural itu sendiri.Nilai-nilai apa saja, dan secara aktual merepresentasikan semangat dan kesadaran kewarganegaraan dalam artefak kehidupan kultural masyarakat tradisional-lokal Sunda di Jawabarat khususnya, akan ditelusur dan dihimpun sebagai salah satu bagian penting konstruksi studi ini.

Bahwa terbentuknya kehidupan bernegara dalam makna bersusunnya interaksi manusia di dalam masyarakat secara bertujuan, untuk saling melindungi dan menguatkan ketertiban dan keselamatan bersama telah dimulai dan sama tuanya dengan umur peradaban umat manusia. Tergambar kuat jejaknya dalam bentuk tradisi kultural kelompok etnik / bangsa hingga terjelma organisasi 
kekuatan untuk melindungi kepentingan bersama dari berbagai tantangan antar bangsa lain dalam ujud negara. Dengan kata lain, terlahirnya nagara dalam peradaban sebuah masyarakat merupakan penguatan upaya mempertahankan kebersamaan dalam menghadapi tuntutan kebutuhan hidup itu sendiri secara internal, dan tumbuhnya tantangan berupa konflik hingga ancaman keamanan yang datang dari luar. Kuatnya kebersatuan dan kesadar-taatan segenap anggota komunitas terhadap keberadaan sistem adat dan kekuasaan penyelenggara pemerintahan di dalam masyarakat tradisional menjadi modal sosial pertama dalam berdiri kokohnya sebuah negara. Oleh karena itu, bersandar pada homogenitas tradisi ancaman dan tantangan terhadap koeksistensi negara hanya datang dari luar, seiring terjadinya perhubungan dengan koeksistensi negara suku bangsa dari luar. Namun demikian, dikenalnya keberadaan negara dengan konstruksi sosial budaya masyarakat yang menjadi lingkupnya, karena terjadinya hubungan dengan dunia luar, baik dengan suku bangsa di Nusantara itu sendiri, maupun dengan sesama bangsa Asia lainnya, yakni India, Cina dan Arab - yang sebagian dari mereka kemudian menjadikan bumi Nusantara sebagai tanah airnya pula, dengan menjadi manusia dan warganegara Indonesia seiring terpetiknya kemerdekaan bagi segenap anak bangsa Indonesia, sejak hari 17 bulan 8 tahun 1945.

\section{Kajian Nilai-Moral dalam Ungkapan Kultural Masyarakat Sunda.}

Ungkapan yang memiliki bentuk khusus tidak sebagaimana ujaran biasa, diapresiasi oleh komunitas penggunanya (pemakai bahasa) pada satuan budaya sebagai buah karya sastra kolektif di dalam kehidupan etnik Sunda, sebagaimana adanya dalam khasanah kesusastraan dan bahasa lainnyadisebut idiomatik (pakeman basa). Adalah salah satu ujud media komunikasi yang hidup dalam keseharian pergaulan masyarakat, secara konseptual jumlahnya lebih banyak dari bentuk yang lainnya, dikenal dengan sebutan Babasan dan Paribasa.Babasan asal kata dari ba-basa-an, merupakan ungkapan lisan dalam kehidupan keseharian orang Sunda yang memiliki maksud berbeda atau tidak selalu sama dengan makna leksikal. Sebagai contoh "gede hulu; bengkok tikoro; amis budi; getas harupaten,” dsb. Sedangkan paribasa, kendati telah menjadi ungkapan keseharian, bentuknya menunjukkan nilai yang lebih tinggi dari ungkapan spontan, berupa pilihan kata lebih bersifat susastra. Paribasa dalam bahasa Indonesia disebut Peribahasa, adalah salah satu jenis ungkapan yang hidup dalam keseharian manusia dan masyarakat pengguna budaya dan bahasa dimaksud. Berbeda sedikit dalam ujudnya, paribasa sebagai ungkapan tetap, bisa puitis dan bermakna simbolis berisi petuah, pendorong semangat terhadap pilihan berperilaku baik. Di dalam Ensiklopedi Sunda dijelaskan bahwa ungkapan bahasa yang tetap susunannya dan menjadi bagian dari tradisi lisan. Peribahasa dalam logat Melayu, atau disebut paribasa dalam bahasa Sunda banyak mengambil unsur kehidupan di pedusunan yang agraris sebagai bahan perbandingan. seperti dihurung suluhkeun, dikompet daunkeun samadengan dijadikan satu antara yang baik dan yang jelek, deukeut deukeut anak taleus dsb. Dalam paribasa Sunda kadang-kadang dipergunakan juga kata-kata bahasa Jawa, dengan dua kemungkinan yakni tadinya berasal dari bahasa Jawa atau untuk maksud supaya lebih mudah diingat. 
Bahwa isi atau makna yang terkandung dalam ungkapan babasan maupun paribasa sebagian besar menggambarkan keadaan baik atau buruk terkait suasana jiwa, (batin, perasaan perorangan), peruntungan, hubungan sosial hingga sikap dan perilaku yang terlahir dalam ucapan dan tindakan diri sebagai pribadi. Karena itu, dari sejumlah ungkapan berupa babasan dan paribasa sebagai unsur kekayaan sastra lisan yang hidup di tengah masyarakat pendukungnya,dapat diklasifikasi berdasar karakterisasi isi dan maknanya menjadi sejumlah petatah-petitih yang dalam bahasa Sunda disebut papagah-peupeujeuh bagi kepentingan penanaman nilai-moral, budi pekerti di dalam kerangka pembentukan 'pribadi' sebagai anggota keluarga dan warga masyarakat (Negara). Sebagian lainnya, tidak dipetik dalam studi ini karena merupakan ungkapan yang isi, bahasa dan maknanya dipandang tidak relevan bagi keperluan pendidikan, baik dalam keluarga, masyarakat dan negara.

\section{Analisis Semantik dalam Merekonstruksi Muatan Nilai-Moral kedalam Tema Kewarganegaraan}

\section{a. Teori Semantik sebagai Kajian Kebahasaan}

Secara sederhana 'semantik' diartikan sebagai ilmu berkenaan dengan makna yang terkandung (meaning) di dalam bahasa. Sebagai sebuah cabang ilmu di dalam bahasa (linguistik), 'semantik' memiliki historis dan peristilahan lain yang dipergunakan untuk maksud tersebut, seperti : "signifik, semasiologi, semologi, semiotic, sememik, dan semik.” (Dajayasudarma: 1993:4), Namun kemudian para akhli yang menekuni perkembangan ilmu ini, seperti : Palmer (1876) Lyons (1977) dan Leech (1974) menggunakan Istilah Semantics sebagaimana digunakan dalam bahasa Inggris, yang konon berasal dari bahasa Yunani 'semainein' (“yang bermakna”; "bermakna”; "berarti”) dan diterima dalam bahasa Indonesia menjadi Semantik. (Slametmulyana dalam Djayasudarma, 1933:22),

Selain berhubungan dengan sub-kajian lain di dalam induk keilmuannya, yakni linguistik', semantikberhubungan pula dengan bidang ilmu lain, setidaknya dengan Filsafat dan Psikologi. Dua bidang keilmuan ini menempatan prilaku manusia sedikitnya sebagai bagian dari, dan keseluruhan objek kajian utama, sedangkan bahasa dan maknanya tidak bisa dipisahkan dari realitas tindakan manusia baik secara perseorangan maupun dalam lingkup sosial dan kebudayaannya. Karena itu, untuk memahami sejumlah ungkapan sebagai sistem nilai dan keyakinan di dalam konteks kebudayaan sebuah masyarakat, diperlukan pendekatan analisis yang memuungkinkan menangkap makna dalam arti maksud yang menjadi 'pesan' tersebut tidak saja secara leksikal ataupun gramatikal, melainkan 'kebermaknaan' dalam konteks sosial-kulturalnya. Bahasa dalam arti kata-kata (verbal) disadari selalu menunjukan keterbatasan dibanding loncatan ekspresi manusia dalam setiap kebudayaannya. Sehingga dalam semua sistem bahasa dan kebudayaan anak manusia di dunia, dikenal bentuk ungkapan idiomatik, yang menarik pemiliknya dan turut berperan dalam mengembangkan, memelihara nilai-nilai kebudayaan dan peradabannya. 


\section{b. Rekonstruksi Model Pengembangan Moral-Kewarganegaraan Berbasis Nilai-Nilai Kultural-Tradisional Lokal Sunda.}

Karena itu, untuk mencapai pembuahan sempurna dari studi dan pengembangan program pendidikan kewarganegaraan baik melalui proses kurikulum di sekolah hingga organisasi kemasyarakatan, dapat dilakukan pendekatan strategis yang memungkinkan terjadi proses resonansi antara komponen kemampuan mental-psikologis dan lingkungan sosial-kultural masingmasing individu (subjek) warganegara.Berikut ini dipetakan model meta morfosis sosial pencapaian standar performansi warganegara yang diharapkan (Good Citizenship) dapat dibentuk melalui aktualisasi nilai-nilai yang ada di dalam lingkup kehidupan sosial-kultural dalam tujuh indikator moral dasar berdasar tema Kewarganegaraan sebagai reduksi dari sejumlah nilai-moral yang hidup dan populer pada tataran nasional dan universal, yakni : 1) sebagai pribadi yang ramah, santun terbuka terhadap sesama pribadi warganegara lainnya karena tahu dan sadar akan dirinya (tahu diri, rendah hati); 2) kecenderungan kemampuan bersikap sabar, ikhlas, besar hati dalam menghadapi persoalan, situasi psikologis yang kurang menyenangkan (kesabaran, kebesar-hatian), kecenderungan bersikap terbuka, lurus, jujur ke dalam dan keluar sebagai bagian dari aktualisasi dirinya (Kejujuran); 3) menyukai interelasi dan interaksi positif dengan sesama pribadi warganegara lain dalam membangun social capital, berupa semangat kebersamaan dan kesetiakawanan dst., (bersahabat, suka menolong) ; 4) sebagai pribadi yang sadar akan perannya di dalam komunitas sosial dan institusi pekerjaan yang telah mengikat dan menjadi pilihan pengembangan dirinya (pengabdian), kesiagaan diri dalam menghadapi perkembangan, tuntutan dan tantangan serta ancaman dan gangguan dari situasi yang tidak menguntungkan bagi kepentingan bersama (Kesiap-siagaan) yang merupakan aktualisasi Kewaspadaan / Profesionalisme ; 5) Kesanggupan dan kecerdasan dalam mengambil keputusan, membela kehormatan diri dan sesama (Keberanian) yang merupakan aktualisiasi Kekesatriaan / Kewiraan ; 6) Kesukaan yang besar dalam bekerja, ulet, tangguh, ajeg, berorientasi mutu (Pekerjakeras dan cerdas) yang metrupakan aktualisasi kemandirian ; 7) memiliki keteguhan dalam sikap, adil terhadap sesama, arif bijaksana dalam melihat persoalan (kemampuan dalam mewujudkan keadilan dan menyukai kebijaksanaan) yang merupakan aktualisasi Kepemimpinan. berikut :

Ketujuh Tema kunci tersebut secara sinergis dapat diragakan dalam gambar 


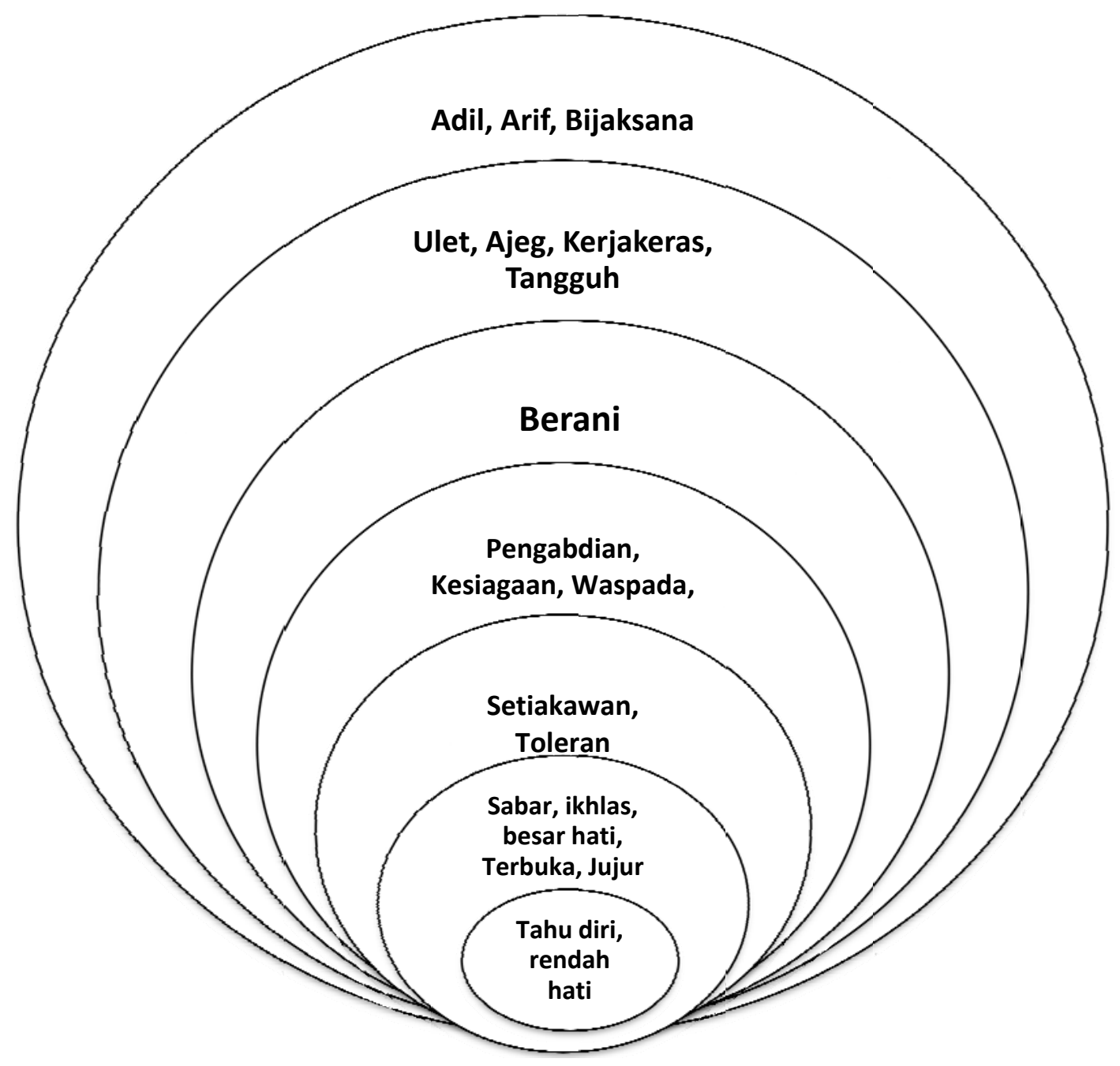

Model Sinergis 7 Tema Indikator Moral Kewarganegaraan (Ichas Hamid, 2012)

\section{METODOLOGI PENELITIAN}

Sesuai dengan lingkup studi dan sifat data yang akan dipetik dalam penelitian ini, pendekatan penelitian ini bersifat deskriptif-kualitatif, maksudnya penghimpunan data dilakukan secara naratif-verbalistik, jikapun dipergunakan matrik tidaklah bersifat numerik, melainkan makna baik tersurat, dan tersirat secara idiomatik. Untuk itu, langkah analisis data dilakukan merujuk kepada Miles dan Hubersman, dimana Tabulasi data secara matrik dipergunakan sebagai bentuk pemetaan klasifikasi dan kategorisasi. Terhadap hasil analisis klasifikasi dan kategorisasi data, kemudian dilakukan analisis semantik dan filosofik berkenaan dengan muatan Nilai-Moral Kewarganegaraan yang menjadi fokus studi ini. Selanjutnya, bagaimana kebermaknaan rujukan konseptual nilai-moral tersebut diujudkan dalam aktualisasinya, seiring identifikasi konseptual semantikfilosofik tersebut ditempuh pengamatan berperan-serta berikut penukilan 
informasi lain yang diperlukan, pada lingkup kehidupan kultural praksis sejumlah tokoh / pribadi yang mewakili anggota masyarakat yang memiliki basis kultural Sunda.

Prosedur yang ditempuh dalam penelitian ini, sesuai dengan karakteristik data dan lingkup persoalan yang menjadi fokusnya,pengumpulan data dan analisisnya telah dimulai dengan memanfaatkan naskah literer yang ada, berupa kumpulan idiomatik lokal Sunda, khususnya berkenaan bentuk Babasan dan Paribasabaik yang telah dihimpun oleh akhli, ataupun berada di luar buku teks yang menjadi sumber utama. Rekonstruksi data awal dilakukan melalui klasifikasi dan kategorisasi sesuai dengan relevansi fokus studi ini, selanjutnya dilakukan analisis semantik hingga tautan filosofik berdasar tema Kewarganegaraan (Citizenship).Selanjutnya,

Yang menjadisubjekpenelitianini, adalahkomunitaspendukungnilaisosialkulturaltradisional-lokalSunda, sebagai kesatuan etnik, yang secara geografis dan demografis menjadi bagian dari warga Jawa Barat dan Banten, dan secara personal, adalah orang-orang yang menunjukan integritas pengetahuan, penalaran, sikap dan tindakan yang mencerminkan sebagai pribadi berbudaya Sunda. Sedangkan yang menjadiobjeknyaadalahsejumlahnilai, keyakinan moral yang tersimpan dalam artefak konseptual berupa Babasan dan Paribasa, dan aktualitasnyayang ada dalam keseharian masyarakat / komunitas pemelihara adat / nilai-nilai tradisional Sunda.

Yang menjadi populasi penelitian ini adalah sejumlah artefak atau jejakbangun kehidupan kultural manusia dan masyarakat etnik Sunda yang ada dalam domisili aslinya di Jawa Barat dan Banten. Adapun yang menjadi samplingnya, sesuai dengan batas dan kepetingan fokus studi ini salah satu bentuk idiomatik yang terhimpun di dalam kerangka konseptual, berupa Babasan dan Paribasa Sunda.

Sesuai dengan fokus masalah dan tujuan penelitian di atas, langkah pengumpulan data yang dilakukan dalam penelitian ini dimulai dari: Pertama, identifikasi dan analisis semantik muatan nilai dan pesan moral yang terdapat dalam satuan ertefak kehidupan kultural masyarakat Sunda, yakni sampel idiomatik mendasar yang memuat / menyebut unsur perilaku manusia di dalamnya, seperti Babasan dan Paribasa; kedua, adalah penukilan fakta sosio kultural pemeliharaan nilai-nilai / keyakinan tradisional lokal Sunda di dalam praksis kehidupan manusia /masyarakat Sunda di Jawa barat

Teknik pengumpulan data yang digunakan dalam penelitian ini adalah sejumlah cara seperti : analisis dokumen, wawancara, dan pengamatan berperanserta, hingga catatan lapangan. Berdasarkan teknik pengumpulan data tersebut dapat diperoleh data kualitatif. Data kualitatif dianalisis dengan menggunakan teknik analisis deskriptif-analitik yang dilakukan secara berkelanjutan untuk kemudian disimpulkan baik secara teoritik dan filosofik. 


\section{PENGUMPULAN DAN ANALISIS DATA PENELITIAN}

\section{Analisis Konseptual Nilai-Moral Kewarganegaraan dalam Ungkapan Kultural Masyarakata Sunda}

Yang dimaksud dengan ungkapan kultural sebagai objek penelitian ini adalah salah satu bentuk artefak, yang dilihat dari sudut kebahasaan (linguistik) disebut idiomatik (pakeman basa). Bahwa di dalam idiomatik atau pakeman basa setiap sistem bahasa terdapat sejumlah gagasan konseptual yang bersifat normatif, sejauh berkenaan dengan perilaku manusia sehinga dapat dihimpun sebagai 'petatah-petitih' yang dalam bahasa lokal sunda disebut papagah-peupeujeuh. Sebagai produk karya sastra kolektif sebuah masyarakat, dan karenanya memiliki nilai susastra dari bentuknya, satuan ungkapan yang menunjukan karakteristik idiomatik di dalam bahasa Sunda disebut Babasan dan Paribasa. Sesuai fokus studi ini, tidak seluruh jenis babasan dan paribasa yang terhimpun di dalam literasi berupa Kumpulan Babasan dan Paribasa yang disusun secara alfabet oleh akhlinya, antara lain Rahayu Tamsyah (1996) dan Ayip Rosidi (2011), seutuhnya memenuhi kebutuhan studi ini. Sesuai dengan fokus tujuan studi ini, menukil isi pesan dan bukan semata bentuk, karena itu tidak seluruh ungkapan yang ada dalam babasan dan paribasa berisi pesan moral atau merupakan papagah dan peupeujeuh orang tua bersifat normatif. Namun juga harus ditambahkan kedalam konstruksi data atas beberapa temuan yang tidak tersebut di dalam kedua buku yang dijadikan rujukan. Berikut ini, dilakukan analisis deskripsi atas sejumlah babasan dan paribasa yang berhasil diidentifkasi, diklasifikasi, dikategorisasi, dan ditandai sebagai satuan data yang memenuhi karakterisasi tema Kewarganegaraan.

\section{a. Analisis Muatan Nilai-Moral Kewarganegaraan dalam Babasan-Paribasa}

Berkenaan dengan BabasantermasukParibasa, sesuai dengan karakteristiknya, bahwa meski terlahir dan berkembang sebagai produk kolektif masyarakat dan karenanya bersifat tuturan atau lisan. Sebagai bahan pelajaran bahasa dan sastra di sekolah telah dikemas menjadi sebuah karya literer. Yang pertama, BabaranBabasan dan Paribasa Sunda karya Ayip Rosidi, yang merupakan hasil penukilan dari sejumlah karya sastra Sunda yang hidup seiring perkembangan kesusastraan lokal (Sunda) Nusantara di tanah air; dan kedua, 1000 Babasan Jeung Paribasa Sunda, susunan Rahayu Tamsyah dkk.; Melalui telaah dokumentasi terhadap kedua sumber tersebut, ditambah beberapa sejauh tidak terdapat dalam salah satu atau kedua sumber tersebut, dipetikan sebagai deskripsi data khususnya berkenaan dengan ajaran moral dalam bentuk tuntunan prilaku baik dan buruk.. Karena itu, sejumlah yang isinya tidak menggambarkan kaitan dengan tuntunan perilaku, seperti menggambarkan keadaan / kondisi yang tidak dikehendaki ada pada diri seseorang, bersifat rasial hingga ungkapan yang tidak patut diucapkan dikalangan kaum terpelajar, tidak termasuk yang dipetik. 
Tabel 1

Analisis Muatan Nilai-Moral Kewarganegaraan Dalam IdiomatikBabasan dan Paribasa Sunda

\begin{tabular}{|c|c|c|c|c|}
\hline No & Babasan & & Paribasa & $\begin{array}{l}\text { Tema } \\
\text { Kunci }\end{array}$ \\
\hline \multirow[t]{10}{*}{1} & Amis budi & 1 & $\begin{array}{l}\text { Ari diarah supana, } \\
\text { kudu dijaga catangna }\end{array}$ & \multirow{10}{*}{$\begin{array}{l}\text { Kerendahan } \\
\text { hati, tahu } \\
\text { diri. }\end{array}$} \\
\hline & $\begin{array}{l}\text { Datang katingali tarang, } \\
\text { undur katingali punduk }\end{array}$ & 2 & Ati putih badan bodas & \\
\hline & Dibeuweung diutahkeun & 3 & & \\
\hline & Euweuh elmu panungtungan & 4 & & \\
\hline & Galegeh gado & 5 & & \\
\hline & $\begin{array}{l}\text { Hade ku omong goreng ku } \\
\text { omong }\end{array}$ & 6 & & \\
\hline & Handap asor & 7 & & \\
\hline & Ngembang genjer & 8 & & \\
\hline & $\begin{array}{l}\text { Ngukur ka kujur nimbang } \\
\text { ka awak }\end{array}$ & 9 & & \\
\hline & $\begin{array}{l}\text { Pondok jodo panjang } \\
\text { baraya }\end{array}$ & 10 & & \\
\hline \multirow[t]{11}{*}{2} & $\begin{array}{l}\text { Teu aya geuneuk } \\
\text { maleukmeuk }\end{array}$ & 1 & Ambek sadu santa budi & \multirow{11}{*}{$\begin{array}{l}\text { Kesabaran, } \\
\text { Keikhlasan, } \\
\text { Kepuasan, } \\
\text { Kejujuran, } \\
\text { keterbukaan }\end{array}$} \\
\hline & $\begin{array}{l}\text { Buruk-buruk papan jati, } \\
\text { burung palung dulur } \\
\text { sorangan }\end{array}$ & 2 & $\begin{array}{l}\text { Kajeun pait heula amis } \\
\text { tungtung, manan amis } \\
\text { heula pait tuntungna }\end{array}$ & \\
\hline & $\begin{array}{l}\text { Caang bulan opat welas, } \\
\text { jalan gede sasapuan }\end{array}$ & 3 & Leuleus jeujeur liat tali & \\
\hline & Clik putih clak herang & 4 & $\begin{array}{l}\text { Mending kendor } \\
\text { ngagembol, tibatan } \\
\text { gancang pincang }\end{array}$ & \\
\hline & Lali rabi tegang pati & 5 & & \\
\hline & Nungtut bari ngeusi & 6 & & \\
\hline & Pada rubak gede samping & 7 & & \\
\hline & Brukbrak & 8 & & \\
\hline & Saujratna & 9 & & \\
\hline & Satarabasna & 10 & & \\
\hline & Teu sumput salindung & 11 & & \\
\hline \multirow[t]{2}{*}{3} & Rempug jukung sauyunan & 1 & $\begin{array}{l}\text { Bengkung ngariung } \\
\text { bongkok ngaronyok }\end{array}$ & \multirow{2}{*}{$\begin{array}{l}\text { Kebersamaa } \\
\mathrm{n}, \\
\text { kesetiakawa } \\
\text { nan, solider, } \\
\text { cinta } \\
\end{array}$} \\
\hline & $\begin{array}{l}\text { Sabata sarimbagan, } \\
\text { sauyunan, layeut }\end{array}$ & 2 & $\begin{array}{l}\text { Ulah cara ka kembang } \\
\text { malati, kudu cara ka } \\
\text { picung }\end{array}$ & \\
\hline
\end{tabular}




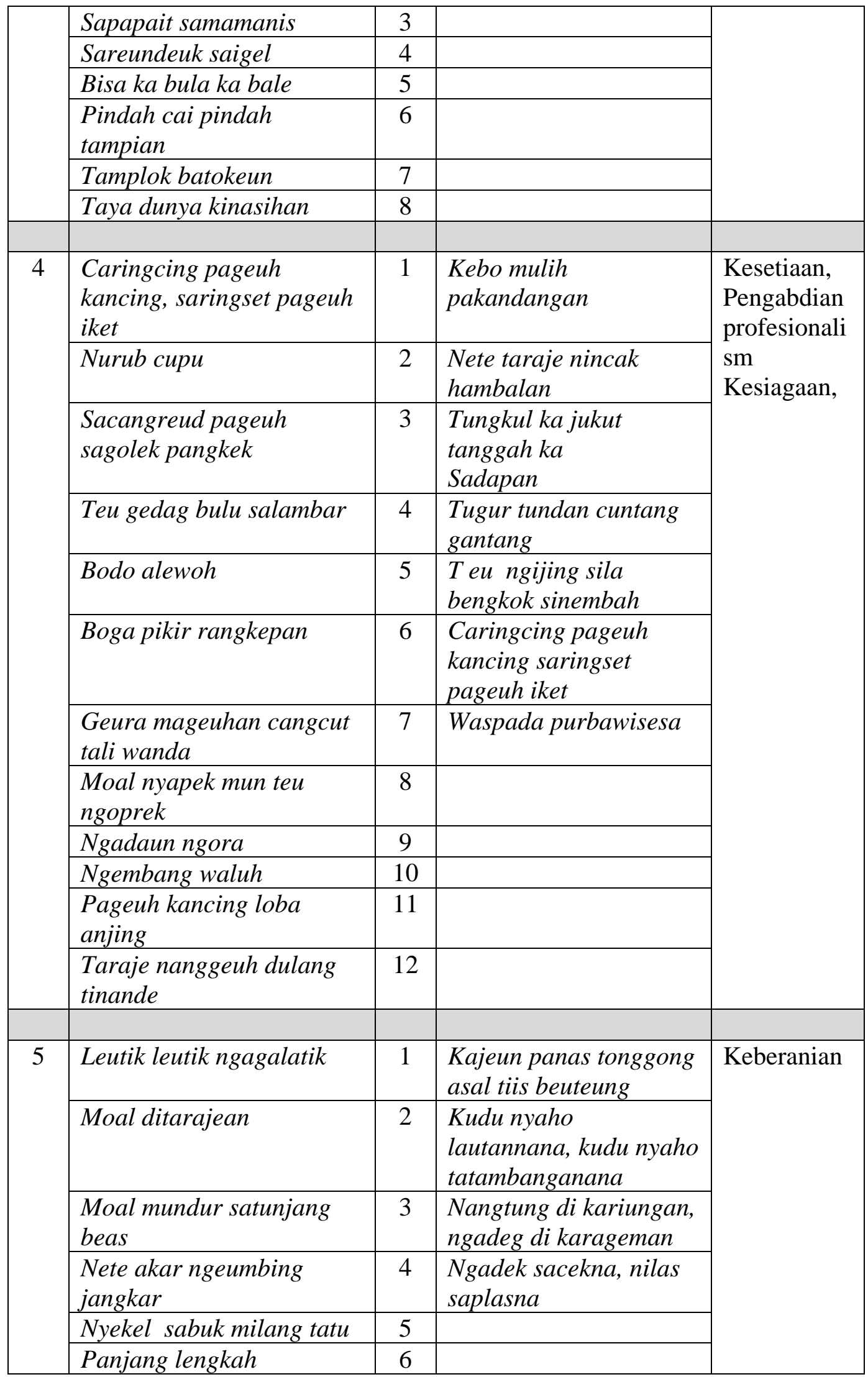




\begin{tabular}{|c|c|c|c|c|}
\hline & & & & \\
\hline \multirow[t]{25}{*}{6} & $\begin{array}{l}\text { Dug hulu pet nyawa, dug } \\
\text { tinetek }\end{array}$ & 1 & Batok bulu eusi madu & \multirow{25}{*}{$\begin{array}{l}\text { Keajegan, } \\
\text { Keuletan } \\
\text { Ketangguhan, } \\
\text { Kerjakeras, } \\
\text { kerja cerdas }\end{array}$} \\
\hline & $\begin{array}{l}\text { Elmu tungtut dunya siar, } \\
\text { sukan-sukan sakadarna }\end{array}$ & 2 & $\begin{array}{l}\text { Cikaracak ninggang } \\
\text { batu, laun-laun jadi } \\
\text { legok }\end{array}$ & \\
\hline & Gugon tuhon & 3 & $\begin{array}{l}\text { Ka hareup ngala } \\
\text { sajeujeuh, katukang } \\
\text { ngala sajeungkal }\end{array}$ & \\
\hline & Gurat batu & 4 & $\begin{array}{l}\text { Legok tapak genteng } \\
\text { kadek }\end{array}$ & \\
\hline & Hampang birit & 5 & Leuleus kejo poena & \\
\hline & $\begin{array}{l}\text { Henteu unggut kalinduan } \\
\text { henteu gedag kaanginan }\end{array}$ & 6 & $\begin{array}{l}\text { Mangkok emas eusi } \\
\text { madu }\end{array}$ & \\
\hline & $\begin{array}{l}\text { Herang caina beunang } \\
\text { laukna }\end{array}$ & 7 & $\begin{array}{l}\text { Meber-meber totopong } \\
\text { heureut }\end{array}$ & \\
\hline & $\begin{array}{l}\text { Indung hukum bapa } \\
\text { darigama }\end{array}$ & 8 & & \\
\hline & Jongjon bontos & 9 & & \\
\hline & Kudu bisa ngeureut pakeun & 10 & & \\
\hline & Kujang dua pangadekna & 11 & & \\
\hline & Kuru cileuh kentel peujit & 12 & & \\
\hline & Leuleus awak & 13 & & \\
\hline & $\begin{array}{l}\text { Lungguh tutut bodo keong, } \\
\text { sawah sakotak kaider } \\
\text { kabeh }\end{array}$ & 14 & & \\
\hline & Ngembang jaat, jalingeur & 15 & & \\
\hline & $\begin{array}{l}\text { Perlu kasambut sunat } \\
\text { kalampah }\end{array}$ & 16 & & \\
\hline & $\begin{array}{l}\text { Pondok catur panjang } \\
\text { maksud }\end{array}$ & 17 & & \\
\hline & $\begin{array}{l}\text { Saciduh metu saucap } \\
\text { nyata }\end{array}$ & 18 & & \\
\hline & Saeutik mahi, loba nyesa & 19 & & \\
\hline & Taya kabau & 20 & & \\
\hline & Teguh pancuh & 21 & & \\
\hline & Teu didingding kelir & 22 & & \\
\hline & Teu eleh geleng & 23 & & \\
\hline & Teu pindo gawe & 24 & & \\
\hline & Ti susut tidungdung & 25 & & \\
\hline \multirow[t]{3}{*}{7} & Adil paramarta & 1 & Giri lungsi tanpahingan & \multirow{3}{*}{$\begin{array}{l}\text { Keadilan, } \\
\text { kearif- } \\
\text { wijaksanaan }\end{array}$} \\
\hline & $\begin{array}{l}\text { Bobot pangayon timbang } \\
\text { taraju }\end{array}$ & 2 & $\begin{array}{l}\text { Landung kandungan laer } \\
\text { aisan }\end{array}$ & \\
\hline & Geus aya dina pesak & 3 & & \\
\hline
\end{tabular}




\begin{tabular}{|l|c|c|l|}
\hline Hade gogog hade tagog & 4 & \\
\hline Jalma cepet bener & 5 & \\
\hline Jalma masagi & 6 & \\
\hline Kolot pawongan & 7 & \\
\hline $\begin{array}{l}\text { Lalaki langit lalanang } \\
\text { jagat }\end{array}$ & 8 & \\
\hline Lantip budi & 9 & \\
\hline Nyaho lautannana & 10 & \\
\hline Weruh sadurung winarah & 11 & \\
\hline 71 & & \\
\hline \multicolumn{2}{|c|}{71} & \\
\hline
\end{tabular}

Tabel di atas, mendeskripsikan pemetaan karakterisasi 71 petikan Babasan dan 25 petikan Paribasa berkonotasi positif : 1) 15 babasan dan 2 paribasa merepresentasikan Tema Moral Kewarganegaraan-1, yakni : 'Kerendahan hati, tahu diri' ;2) 11 babasan dan 4 paribasa merepresentasikan Tema Moral Kewarganegaraan-2, yakni : 'Kesabaran, Keikhlasan, Kepuasan, Kejujuran, Keterbukaan' : 3) 8 babasan dan 2 paribasa merepresentasikan Tema Moral Kewarganegaraan-3, yakni ; Kebersamaan, kesetiakawanan, solider, cinta; 4) 12 babasan dan 7 paribasa merepresentasikan Tema Moral Kewarganegaraan-4, yakni : Kesetiaan, Pengabdian, Professionalisme, Kesiagaan; 5) 6 babasan dan 4 paribasa merepresentasikanTema Moral Kewarganegaraan-5, yakni : Keberanian; 6) 25 babasan dan 7 paribasa merepresentasikan Tema Moral Kewarganegaraan -6, yakni : Keajegan, Keuletan Ketangguhan, Kerjakeras, Kerja cerdas; dan 7) 11babasan dan 2 paribasa merepresentasikan Tema Moral Kewarganegaraan-7, yakni : Keadilan, kearif-wijaksanaan.

\section{Rekonstruksi Model Pengembangan Moral Kewarganegaraan Berbasis Nilai-Nilai Kultural-Tradisional Lokal Sunda}

Sebagaimana negara dalam ujudnya, politik dalam aktifitas di dalamnya memiliki tujuan mendasar yang disandarkan pada cita-cita agung yang luhur dan mulia serta sempurna dari kehendak manusia. Manusia dengan puncak kesadaran yang bisa dicapainya, tiadalah akan memilih cara-cara dan tujuan bodoh yang bisa dilihatnya dari perilaku makhluk yang lebih rendah dari dirinya, tetapi dapat mengapresiasi segala keindahan yang mempesona, meski tidak melekat dan menjadi dirinya yang diciptakan Zat Maha Pencipta melengkapi keindahan kehidupan ini. Bertolak dari ketiadaan memiliki apa yang secara langsung berguna bagi kekuatan, dan kenyamanan di dalam menjalani kehidupan sebagaimana makhluk hewan lainnya. Kesadaran manusia akan ketidak sempurnaan tumbuh melahirkan kesanggupan mengatasi kekurang sempurnaan dalam mempertahankan hidupnya, karena dari situlah diri manusia menemukan pikiran, dan kemampuan menggunakan pikiran untuk mempertahankan diri hingga menguasai alam bagi kelangsungan hidupnya, di atas sekalian makhluk lainnya. Ketika seorang diri manusia berdiri, memandang tegak kepada dirinya sendiri, membandingkan dari sekalian makhluk yang ada mengitari hidupnya, sempurnalah keberadaan dirinya, sebagai salah satu kekuatan yang berkehendak untuk memimpin dalam arti mengatur kelangsungan kehidupan. Tetapi realitas 
manusia diciptakan mengisi kelangsungan kehidupan bersama manusia lainnya, dan dalam kerangka menjalani kedirian ada bersama manusia lain dari waktu ke waktu, dalam perkembangan hampir tak terbatas dalam ujud masyarakat, tiadalah senantiasa berpagut tujuannya. Namun demikian, kemampuan berkehendak dan mengatur kehidupan bersama menjadi fitrah lahirnya 'politik' di tangan manusia.

Politik, hanyalah cara-cara atau jalan dan alat yang bisa dilakukan oleh berbagai diri manusia dengan masing-masing sifat yang berbeda. Kendati ujud negara yang pertama, boleh jadi merupakan buah karya sebuah generasi dari kelompok manusia yang mungkin tidak lebih sempurna, tetapi produk dari suatu proses dan tujuan yang baik dari kehendak dasar diri manusia di dalam kelompoknya itu. Karena itu, jika itu adalah sebuah monarchi sekalipun, ketiadaan sesudahnya terbukti meninggalkan kesan dan kenangan, harum wangi dari sebuah nama yang dicinta, karena bisa disebut "ratu adil bijaksana", ketika yang dilakukan hingga ditinggalkannya adalah kenyataan keberhasilan menciptakan kelangsungan kehidupan negara dengan segala kejayaan yang berarti, dengan kesertaan segenap rakyat sebagai 'kaula-negara' pendukungnya. Apa yang dimiliki rakyat dari badan hingga hartanya, toh pati jiwa raga demi negara, segenap rakyat bersuka-rela dan bangga menjadi abdi-nagara, karena negara menjadi simbol perjuangan dan pengabdian bagi kehidupannya. Bersama terbentuknya negara, tentunya oleh adanya kehendak 'seseorang' atau 'orangorang' yang memiliki penguasaan 'ilmu dan kesadaran' dalam memimpin kaumnya, dimulai dari kepentingan mengurus, mengatur kehidupan bersama mengkristal menjadi energi dan cara-cara yang di dalam bahasa Yunani disebut politea atau 'politik', adalah apa yang harus ada atau dimiliki oleh orangperorang untuk keperluan "ngaheuyeuk dayeuh ngolah nagara", yang didalamnya tersirat kemauan dan kemampuan mewujudkan tujuan negara karena itu untuk memastikan pencapaian tujuannya, tidak dapat tidak mensyaratkan adanya kematangan pribadi dalam ujud semangat yang hidup (menyala) bagi segala kebaikan dan kepentingan umat manusia dan alam yang menjadi lingkupnya; Aristoteles menyebutnya "Ethos" sebagai indikator kekuatan pertama dan utama yang harus dimiliki segenap warga-negara hingga para pemimpin negara. Berikutnya meminjam istilah Aristoteles lainnya adalah Logos, yakni kecukupan ilmu pengetahuan dan penalaran dalam memecahkan permasalahan kemasyarakatan dan kenegaraan; dan Pathos, yaitu kemampuan seni dalam menggerakan orang-orang atau anggota masyarakat secara positif (baik) dan konstruktif.Sebagaimana maknanya, di masa lalu terutama disyaratkan menjadi bagian yang harus dimiliki para pemimpin politik (masyarakat), sedangkan bagi kebanyakan kaula-negara yang tidak beroleh bekal pendidikan dan kecakapan, boleh tidak diharapkan - bukan tidak penting, tetapi dua hal itu tidak mungkin terdapat dari orang yang secara nyata tidak beroleh 'pendidikan'. Karena itu, pendidikan dan hanya dengan pendidikan, hajat pembentukan ethos, tidak terlepas dari ikhtiar pengembangan kemampuan logos dan pathos, menjadi satu kesatuan model dasar pendidikan politik bagi segenap anak bangsa - seiring penunaian tuntutan konstitusi atas hak-haknya sebagai warganegara. Dengan demikian, trilogi (Hidayat Padmadinata) dan tujuan pendidikan politikkewarganegaraan di dalam praksis kelangsungan hidup bermasyarakat dapat 
ditetapkan : Pertama, terbentuknya integrasi kompetensi dasar kewarganegaraan yang secara potensial merupakan ranah penguasaan pengetahuan (logos), mencakup : 1) tempat dan kedudukan, hak dan kewajiban diri sendiri sebagai anggota keluarga, warga masyarakat dan Negara; 2) norma atau peraturan yang hidup dalam suasana kejiwaaan dan praksis kehidupan institusi keluarga, organisasi kemasyarakatan, idiologi kebangsaan dan kenegaraan; Kedua, kemampuan seni kepemimpinan (pathos), dan integritas kekuatan diri dalam mengontrol (Ethos) ... ; Ketiga, Aktualisasi Sikap mental dan Moral (Ethos) yang mengikat kuat dan mendasari segala aktifitas di dalam arena kehidupan bersama, mulai dari lingkup paling kecil yakni keluarga, masyarakat hingga kesatuan bangsa dan negara. Seiring kepentingan pengembangan pendidikan politikkewarganegaraan khususnya di dalam lingkup kehidupan masyarakat luas, mendasari langkah pencarian akan model praksis pendidikan politik kewarganegaraan Nasional Indonesia saat ini, diantara kekayaan etnisitas yang kita miliki - sebagai anak bangsa pewaris kejayaan Nusantara; dan kekuatan kosmopolitanisme sebagai bagian dari realitas masa depan dunia. Penelusuran dan penghidupan kembali model political-praksis lokal pada berbagai tempat di tanah air dapat dilakukan. Melengkapi acuan teoritik tersebut, dapat digambarkan rekonstruksi model Pendidikan Politik dengan sub-tema Pembentukan Ethos Kewarganegaraan berbasis Nilai-nilai Kultural Lokal-Tradisional Sunda sebagai berikut :

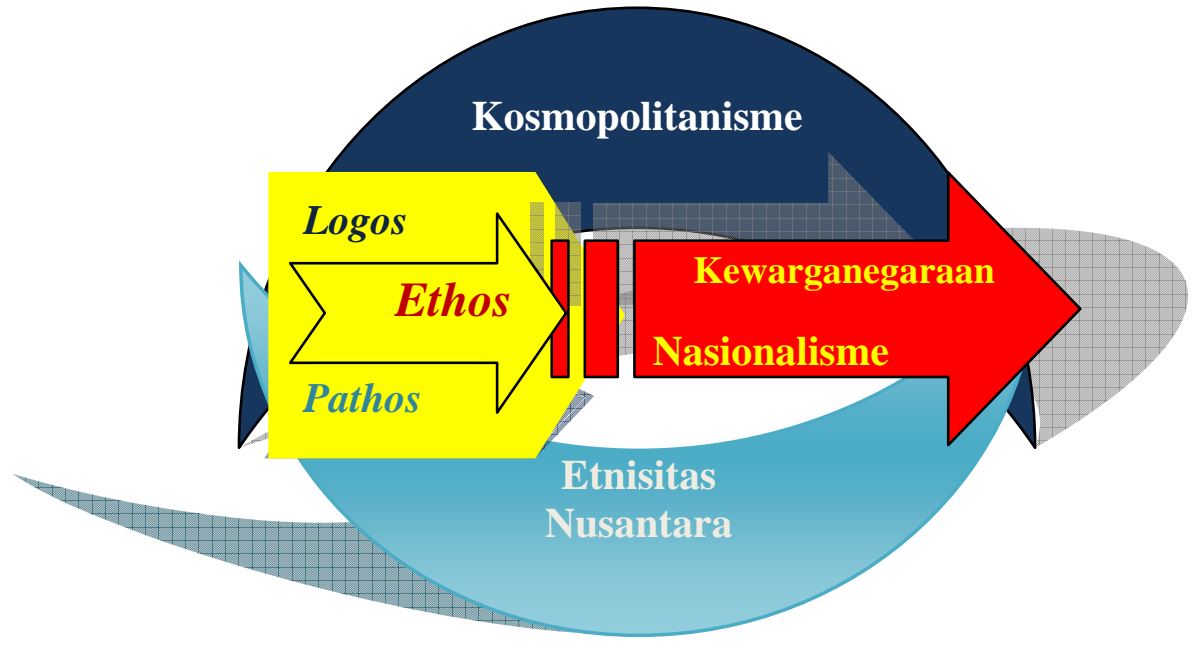

\section{Gambar 1 : \\ Rekonstruksi Model Pengembangan Ethos Kewarganegaraan berbasis Etnisitas Lokal Nusantara}

Menyadari bahwa terbentuknya ethos (sikap mental dan moral) tidak selalu terjadi dengan sendirinya seiring pengembangan logos dan kemampuan pathos dalam pendidikan Politik Kewarganegaraan; Penetrasi kegiatan pembelajaran konstruksi pengetahuan politik-kewarganegaraan sebagai satuan keilmuan secara akademis, dalam perspektif perkembangan dunia ilmu dan perubahan realitas kehidupan itu sendiri, tidak selalu langsung mampu 
menggugah terbangkitnya kesadaran atas persoalan krusial yang dihadapi bersama dalam kehidupan berbangsa dan bernegara; Konstruksi dan koeksistensi negarabangsa jika hanya dikemas dan ditangkap oleh peserta belajar di dalam suasana akademik, akan membuahkan kumulasi pengetahuan dan pemahaman parsial tentang negara dan bangsanya, tetapi tidak memberi celah langsung bagi terbentuknya kesadaran positif dan konstruktif yang diharapkan terbentuk dari setiap individu warganegara.

Karena Negara di dalam dinamika terlebih dalam format respublica dengan atas nama hak-hak yang sama bagi segala warganegara, selalu menjadi ruang terbuka untuk setiap kekuatan dan dengan segala kekuatan untuk merebut dan memenangkan atau sedikitnya ambil bagian di dalam menjalankan kekuasaan. Sementara rakyat kebanyakan yang disebut di dalam teori demokrasi sebagai sumber kekuasaan, ada sepenuhnya dalam ketidak berdayaan. Negara di negara berkembang bagi kebanyakan rakyat yang hidup di garis belakang menjadi dunianya 'politisi' (kumaha anu dibendo), sementara diantara 'politisi' anak kandung kebodohan rakyat itu sendiri merepresentasikan ketidak pedulian terhadap tujuan benar negara dan harapan besar rakyatnya. Boleh jadi juga, karena diantara kita yang berkiprah di arena politik dan bangga disebut politisi, meski tidak sedikit rakyat mencibirnya, karena juga paham bahwa diantara mereka tidak beroleh bekal pendidikan politik-kewarganegaraan yang memadai - dalam perspektif integritas etik-filosofik dengan dirinya, jika kenampakan yang nyata adalah ketidak mauan dan ketidak mampuan berpikir dan bekerja untuk tujuan luhur cita-cita negara dan bangsanya. Untuk itu, perlu ada pendekatan yang dapat menghubungkan antara proses pengembangan pengetahuan dan penalaran terhadap negara-bangsa yang harus menjadi symbol kebanggaan dan sekalipus alat perjuangan mencapai tujuan hidup bernegara-bangsa bagi dirinya setidaknya mulai sebagai warganegara - selebihnya, sesuai dengan tuntutan dan perkembangan karier profesional satuan pribadi di dalam lingkup kehidupan masyarakat, negara dan bangsa.

\section{E. KESIMPULAN DAN REKOMENDASI}

1. Kesimpulan

\section{a. Konseptualisasi Nilai-Moral Kewarganegaraan dalam Babasan dan Paribasa Sunda}

Babasan dan Paribasa sebagai salah satu idiomatik bentuk ujaran, sesuai dengan sifat verbalnya adalah merupakan bentuk pengembangan idiom pertama atau sumber dari yang lainnya, sehingga merupakan kumpulan yang menyimpan pra-cetak yang mendasar dalam bentuk ungkapan yang terlahir dari interaksi manusia di dalam komunitas kulturalnya. Karena itu, sebagai ungkapan yang dilahirkan terutama secara lisan dan mengandung nilai sastra; sejumlah babasan dan paribasa dianggap pula sebagai salah satu bentuk produk karya kolektif masyarakat. Sebagai produk kultural lisan, ia ada di dalam interaksi kehidupan langsung, antar diri pribadi manusia di dalam konteks masyarakat, bukan dari imajinasi atau konsepsi pikiran yang terlepas dari realitas kehidupan yang menjadi sumbernya. Karena itu, keberadaan nilai-nilai berkenaan dengan kepatutan untuk dilakukan atau tidak dilakukan sebagaimana ajaran moral yang dapat bersifat 
normatif, di dalam ungkapan itu dilekatkan langsung sosok persona dalam hubungan dengan lingkup komunitasnya. Penyusunan kedalam bentuk kumpulan menjadi berujud literer, seperti dilakukan Rahayu Tamsyah (1996) dan Ayip Rosidi (2005) sejauh bagi keperluan suplemen pembelajaran di sekolah tentu memenuhi batasan praksisnya, terutama dari perspektif pengetahuan kesusastraan, tetapi tidak menjadi sumber final studi ini. Meski telah memberikan sumbangan yang tidak kecil, setidaknya saat mengawali kegiatan penelitian ini. Ketidak cukupan sumber tertulis yang ada, dirasakan saat dilakukan pemetaan berdasar karakterisasi pemaknaannya secara semantik. Beberapa ungkapan yang dapat memenuhi representasinya, meski tidak banyak harus dimasukan tidak bersumber dari suplai data tertulis tersebut. Namun demikian, keberadaan dan kedudukan ungkapan idiomatik dalam ujud keseluruhan budaya masyarakat Sunda, dari bentuk yang disebut : pertama, kedua, dst. masing-masing adalah : bangun konseptual yang menjadi sumber ajaran nilai-moral bagi segenap komunitas pendukung sistem kebudayaan Sunda, yang belum final sebagai sebuah produk budaya, jika tidak diwujudkan dalam realitas kehidupan langsung sehingga diperlukan adanya media artikulasi : pengucapan dan pengungkapan ulang secara multi-dimensional, dan sekaligus sebagai wahana ekspresi dalam berbagai bentuknya.

\section{b. Pengembangan Muatan Konseptual Nila-Moral Kewarganegaraan dalam Babasan dan Paribasa Sunda bagi Kepentingan Praksis Pendidikan}

Merujuk kekayaan idiomatik di dalam tradisi lisan (sastra) Sunda, secara konseptual sebagian besar merupakan pernyataan yang mengandung nilai keyakinan, keberpihakan pada kebaikan (moral) hingga berperan menjadi petatahpetitih (papagah-peupeujeuh), setidaknya untuk sejumlah ungkapan yang berkonotasi positif memenuhi kriteria / kelompok Pangjurung Laku Hade (PLH), dan yang berkonotasi negatif, tetap bermakna dilihat sebagai Panyaram lampah Salah (PLS). Ungkapan lain yang isi, bahasa dan maknanya tidak penting bagi keperluan pendidikan, seperti menggambarkan keadaan diluar persoalan psikologis diri manusia baik sebagai personal maupun sosial, dengan sendirinya tidak termasuk menjadi bagian dari kategori 'petatah-petitih'. Karena itu tidak mengandung muatan Nilai-Moral.

Terhadap sejumlah babasan dan paribasa yang merepresentasikan tuntunan moral, karena itu memliki fungsi-nilai secara instrumental di dalam lingkup pemeliharaan nilai sosial-kultural Sunda, meski dapat disebut jumlahnya namun tidaklah merupakan hasil hitung sebab tidak menjadi tujuan studi ini membuat identifikasi final, melainkan keberadaan dan kebermaknaannya secara semantik, khususnya dari perspektif Pendidikan Kewarganegaraan sebagai salah satu praksis pendidikan nilai-moral dan politik. Untuk itu, melengkapi kerangka studi ini, dilakukan rekonstruksi Tema Nilai-Moral Kewarganegaraan sebagai model jaringan konsep untuk mengelompokan sejumlah ungkapan berupa petatah-petitih (papagah-peupeujeuh) yang secara institusional menjadi bagian dari pranata dalam kehidupan sosial kultural masyarakat etnik Sunda.

Tema Moral Kewarganegaran (TMK) tersebut antara lain : 1) indikator perilaku personal yang bersipat mendasar, seperti sikap ramah, santun terbuka terhadap sesama pribadi warganegara lainnya, karena tahu dan sadar akan dirinya. 
Sehingga di dalam aktualisasinya disebut sebagai sikap tahu diri dan rendah hati rendah hati; 2) Indikator kecenderungan kemampuan bersikap sabar, ikhlas, besar hati dalam menghadapi persoalan, situasi psikologis yang kurang menyenangkan, bersikap terbuka, lurus, jujur ke dalam dan keluar sebagai bagian dari aktualisasi dirinya. Sehingga aktualisasinya merupakan sikap sabar, besar-hati / legawa dan jujur; 3) kecenderungan berperilaku menyukai interelasi dan interaksi positif dengan sesama pribadi warganegara lain dalam membangun social capital, berupa semangat kebersamaan dan kesetiakawanan. Sehingga dalam aktualisasinya nampak sebagai sikap bersahabat dan suka menolong; 4) indikator kecenderungan kemampuan pribadi yang sadar akan perannya di dalam komunitas sosial (pengabdian) dan institusi pekerjaan yang telah mengikat dan menjadi pilihan pengembangan dirinya (profesionalisme), kesiagaan diri dalam menghadapi perkembangan, tuntutan dan tantangan serta ancaman dan gangguan dari situasi yang tidak menguntungkan bagi kepentingan bersama. Yang aktualisasinya merupakan sikap Kewaspadaan dan Profesionalisme ; 5)Indikator Kesanggupan dan kecerdasan dalam mengambil keputusan, membela kehormatan diri dan sesama (Keberanian) yang aktualisiasinya merupakan Kekesatriaan / Kewiraan ; 6)Indikator Kesukaan yang besar dalam bekerja, ulet, tangguh, ajeg, berorientasi mutu (Pekerjakeras dan cerdas) yang aktualisasinya merupakan sikap kemandirian ; 7)indikator kecenderungan keteguhan dalam sikap, adil terhadap sesama, arif bijaksana dalam melihat persoalan (kemampuan dalam mewujudkan keadilan dan menyukai kebijaksanaan) yang aktualisasi merupakan salah satu social investmentKepemimpinan.

\section{Rekomendasi}

Sebagai sebuah studi pendahuluan, hasil studi ini diharapkan menjadi dasar bagi kepentingan penelitian lanjut yang lebih komprehensif berkenaan dengan artefak kehidupan kultural manusia dan masyarakat etnik Sunda, yang secara faktual menunjukan kompleksitasnya. Bahwa realitas penunjukan pemeliharaan, apresiasi dan pelestarian terhadap nilai-nilai tradisional dalam berbagai bentuknya selain dapat ditelusuri keberadaan dan keterpeliharaannya pada sejumlah komunitas / Situs Kampung Adat di pedalaman tatar Sunda. Dapat dilihat pula pada realitas warga masyarakat etnik Sunda yang kesehariannya merupakan warga kota yang tidak terikat pada tradisi secara ketat, namun pada moment dan dalam event tertentu tetap mennjukan jatidirinya sebagai pemilik warisan kultural Sunda sebagai latar belakang etniknya. Untuk itu, studi selanjutnya dapat direkomendasikan, sedikitnya sebagai berikut :

a. Mengidentifikasi sejumlah artefak kehidupan kultural sebagai sumber acuan nilai-moral dan system organisasi dalam praktik kemasyarakatan hingga pemerintahan / kenegaraan

b. Mengembangkan model Konseptual Penanaman Nilai-Moral Kewarganegaraan melalui Proyek Pendidikan Sosial Kultural-Lokal Nusantara dan Global di sekolah dan masyarakat.

c. Mengujicobakan model Pendidikan Kewarganegaraan berbasis dan bertema pemeliharaan sosial kultural Sunda, baik intra-kurikuler, ko-kurikuler maupun ekstra kurikuler. 


\section{DAFTAR PUSTAKA}

Djahiri, Kosasih. (1981), Hakikat Pengajaran PMP dan Model SBM serta Disain Pengajaran PMP. Bandung: P3G Dep.P \& K / Jurusan PKNH IKIP Bandung (1996), Menelusuri Dunia Afektif. Bandung: Lab. Pengajaran PMP IKIP Bandung.,

Djayasudarma, Fatimah, (1993), Semantik (1), Makna Leksikal dan Gramatical, Bandung: Refika Aditama

, (1993), Semantik (2), Pemahaman Ilmu Makna, Bandung: Refika Aditama

Ekadjati, Edi S. (1993), Kebudayaan Sunda jilid 1, Suatu Pendekatan Sejarah, Jakarta : Pustaka Jaya.

, (2003), Kebudayaan Sunda jilid 2, Jaman Pajajaran, Jakarta : Pustaka Jaya.

Fraenkel, Jack R. (1977), How to Teach About Values. New Jersey: Prentice-Hall, Inc., Englewood Cliffts.

Hamid Al-lamri, S. Ichas, (1984), PerbandinganHasil Belajar KuantitatifKualitatif \& Perkiraan Perkembangan Moral Kognitif Atas Faktor Internal-Intelektif, Non-Intelektif dan Keaktifan Siswa di Dalam Interaksi Kelas PMP yang Integratif-Demokratik, (TesisS1) Bandung, Jurusan PMPKN FPIPS IKIP Bandung. (2002), Persepsi Anak Usia Kelas Awal Sekolah Dasar Terhadap Konsep Nilai (Tesis-S2) PPS-UNJ, Jakarta.

(2005), Pengembangan Molekuler Semangat Kebangsaan dan Kewarganegaraan dalam Format Pendidikan Politik di Persekolahan, Jurnal Pendidikan Dasar-ISSN 1829-5606 Volume II No. 4 April 2005.

\& Istianti, Tuti., (2006), Pengembangan Pendidikan Nilai dalam Pembelajaran Pengetahuan Sosial di Sekolah Dasar, Buku Ajar Nasional PGSD, Direktorat Ketenagaan Dirjen Dikti Depdiknas. , (2009), Memintal Serat Halus Bernama Ethos Kewarganegaraan, Jurnal Civicus, Vol. 12 No. 1 Januari 2009. ISSN:1412-5463. Jurusan PKn FPIPS UPI.

(2009), Membangun Nasionalisme Generasi Masa Depan Melalui Penanaman Ethos Kewarganegaraan Pada Anak Usia Dini, Jurnal PKn Progresif Volume 4, Nomor 1, Juni 2009. ISSN 19075332. Prodi PKn FKIP UNS Surakarta.

(2010), Mengembangkan Karakter Kewarganegaraan melalui Kegiatan Ekstrakurikuler Kepanduan di Sekolah dan Masyarakat, Prosiding Seminar Aktualisasi Pendidikan Karakter Bangssa, Bandung : Widya Aksara Press \& Prodi PKn SPs UPI.

, (2010), Mencari Filsafat Pendidikan Kewarganegaraan, Prosiding Seminar Nasional dan Kongres Asosiasi PKn se Indonesia 2010. Bandung : Widya Aksara Press \& Prodi PKn SPs UPI. 
Haricahyono, Cheppy, (1988), Penddidikan Moral Dalam Beberapa Pendekatan. Jakarta: P2LPTK Ditjen Dikti Depdikbud.

Muhadjir, Noeng, (1998), Metodologi Penelitian Kualitatif, Edisi III, Yogyakarta: Rakesarasin

Naisbitt, J (1998), Megatrend Asia: Delapan Megatrend Asia yang Mengubah Dunia, Jakarta PT Gramedia Pustaka Utama.

Pemerintah Republik Indonesia, (2010) Disain Induk : Pembangunan Karakter Bangsa Tahun 2010-2025.

Poespoprodjo, (1987), Interprestasi. Bandung: PT Remaja Rosdakarya. , dan EKT Gilarso, (1999), Logika Ilmu Menalar, Bandung : Pustaka Grafika.

Ratna, Nyoman Kutha, (2010), Metodologi Penelitian, Kajian Budaya dan Ilmu Sosial Humaniora pada Umumnya, Yogyakarta: Pustaka Pelajar.

Rosidi, Ayip (2005) Babasan dan Paribasa. Kabeungharan Basa Sunda, Jilid 1 dan 2. Bandung: Kiblat Buku Utama. , (2009), Manusia Sunda, Bandung: Kiblat Buku Utama. (2011), Kearifan Lokal dalam Perspektif Budaya Sunda, Bandung: Kiblat Buku Utama.

(2011), Perspektif Kebudayaan Sunda Dalam Kesatuan Bangsa Indonesia, Bandung : Pusat Studi Sunda

Somantri, Muh Nu'man (2001), Menggagas Pembaruan Pendidikan IPS, Ed. Dedi Supriadi \& Rohmat Mulyana, PPs-FPIPS UPI dan PT Remaja Rosdakarya.

Smick, David M, (2009), Kiamat Ekonomi Global Terj. Dari The Wordl Curved : Krisis 2007-2008 Barulah Awal .., Daras Books.

Strauss, Anselm \& Juliet Corbin (2003) Dasar-Dasar Penelitian Kualitatif, Terj. M.Shodiq \& Imam Mutaqin, Jogyakarta : Pustaka Pelajar.

Su'eb, R. Ace Hasan, (2007), Wawasan Tembang Sunda, Bandung: Gegersunten. Sudarto (1995), Metodologi Penelitian Filsafat, Jakarta : Raja Grafindo Persada Suryadi, Ace \& Tilaar, HAR (1993) Analisis Kebijakan Pendidikan. Bandung: PT Remaja Rosdakarya.

\& Budimansyah, (2009), Paradigma pembangunan Pendidikan Nasional : Konsep, Teori dan Aplikasi dalam Analisis Kebijakan Publik. Bandung: Widya Aksara Press.

(2009) Peningkatan Mutu Dalam Perspektif Pemikiran Ekonomi Pendidikan. (Makalah) Bandung, UPI..

Tamsyah, Rahayu Budi, Dkk (1994), 1000 Babasan Jeung Paribasa Sunda., Bandung : Pustaka Setia.

(1995), Kamus Ungkapan dan Peribahasa Sunda, Bandung : Pustaka Setia.

, (1996) Pangajaran Sastra Sunda, Bandung : Pustaka Setia.

Tilaar, HAR., (2004), Multikuralisme : Tantangan Global Masa Depan dalam Transformasi Pendidikan Nasional. Jakarta: PT Grasindo.

Ujan, Andre Ata dkk - Editor, (2011), Moralitas Lentera Peradaban Dunia, Jogyakarta : Kanisius. 
Wahab, Abdul Azis \& Sapriya (2011), Teori dan Landasan Pendidikan Kewarganegaraan, Bandung : Alfabeta.

Winataputra, US \& Budimansyah, D., (2007), Civic Education: Konteks, Landasan, Bahan Ajar dan Kultur Kelas. Prodi PKN SPs UPI. 